\title{
The Interrelationship between Potassium, Magnesium and Phosphorus in Potassium-limited Chemostat Cultures of Aerobacter aerogenes
}

\author{
BY D. W. TEMPEST, J. W. DICKS AND J. R. HUNTER \\ Microbiological Research Establishment, Porton Down, Wiltshire
}

(Received 3 March 1966)

\begin{abstract}
SUMMARY
The growth of Aerobacter aerogenes cultures in a chemostat under conditions of $\mathbf{K}^{+}$-limitation was investigated. At a fixed dilution rate there was a linear relationship between bacterial concentration and the $\mathbf{K}^{+}$ concentration in the culture. The extrapolated plot did not pass through the origin, however; this indicated the presence in the medium of substance(s) supporting some growth in the absence of $\mathbf{K}^{+}$. The growth yield varied markedly with the dilution rate; bacterial concentration decreased and the cellular $\mathrm{K}^{+}, \mathrm{Mg}^{2+}$, RNA and phosphorus contents increased as the 'steady-state' growth rate was increased. The yield variation was similar to that observed when either $\mathrm{Mg}^{2+}$ or $\mathrm{PO}_{4}{ }^{3-}$ was the limiting component of the medium. Analysis of $\mathbf{K}^{+}$-limited organisms revealed a molar stoichiometry between cellular $\mathrm{Mg}^{2+}, \mathrm{K}^{+}$and $\mathrm{P}$ (close to $1: 4: 8$, respectively) that was almost independent of growth rate. It is suggested that a precise intracellular $\mathrm{K}^{+}: \mathrm{Mg}^{2+}$ ratio may be of importance for maintaining ribosomal structures in a suitable functional configuration or degree of aggregation, and it is for this purpose that high concentrations of $\mathbf{K}^{+}$are present in growing bacteria. $\mathrm{K}^{+}$-limited $\boldsymbol{A}$. aerogenes cultures oxidized glycerol rapidly, as did washed supensions of these organisms in phosphate buffer $(\mathrm{pH} \mathrm{6.5)}$. Glycerol $(10 \mathrm{~mm})$ accelerated the death-rate of $\mathbf{K}^{+}$-limited bacteria; potassium (15 mM) and magnesium (15 mM) each decreased this glycerol toxicity and, when added together, abolished it. The death-rate of washed $\mathrm{K}^{+}$-limited $\boldsymbol{A}$. aerogenes suspensions in phosphate saline $(\mathrm{pH} \mathrm{6.5)}$ was a function of their 'steady-state' growth rate.
\end{abstract}

\section{INTRODUCTION}

Although most, if not all, bacteria have a requirement for potassium for growth (Lester, 1958), and the potassium content of organisms may be considerable (Rouf, 1964), the physiological basis of this requirement is not fully understood. Lubin \& Kessel (1960) isolated a mutant of Escherichia coli which had a decreased ability to concentrate potassium from the environment and found that the growth rate of this mutant, in a defined medium, was proportional to its intracellular $\mathbf{K}^{+}$concentration. Furthermore, with this mutant Ennis \& Lubin (1961, 1965) showed that when the intracellular $\mathrm{K}^{+}$concentration was decreased to a low value the organisms were unable to synthesize protein, though synthesis of RNA proceeded at a linear rate for some hours. They suggested that these conditions produced a specific impairment of protein synthesis similar to that imparted by chloramphenicol. Eddy \& Hinshelwood (1951) concluded that potassium '.. . is associated with the actual functioning 
of the cell, and is not, at any rate in the full amount, among the permanent structural requisites'. These authors suggested that intracellular potassium was associated with certain intermediates involved in the degradation of carbon substrates (as did Roberts, Roberts \& Cowie, 1949) and that the specificity for this ion resulted from it being of a size suitable for incorporation into a temporary structure involving phosphorylated intermediates and enzyme surfaces. They further suggested that binding afforded protection to the bacteria by excluding hydrogen ions which would have a deleterious effect when present intracellularly in high concentration. Neither the above observations, nor the fact that potassium is an activator of certain enzyme systems (Dixon \& Webb, 1958) seem to explain fully the need for the very high concentrations of potassium found in rapidly growing bacteria.

Since microbial growth can be made dependent on potassium, the concentration of this element in the medium can be adjusted to limit the growth of organisms in a chemostat culture. In such a $\mathbf{K}^{+}$-limited environment the organisms must contain the minimum concentration of potassium necessary to satisfy the structural and functional needs for growth at the imposed rate. Comparison of these organisms with those from chemostat cultures in which other components of the medium limited growth, for example $\mathrm{Mg}^{2+}$-limited organisms (Tempest, Hunter \& Sykes, 1965), and a systematic analysis of the effect of changes in growth rate on the physiology of the organisms in the culture may thus provide an approach to the problem of identifying the structural and functional sites which require the high concentrations of potassium found in the growing organism. The present paper describes the changes in bacterial $\mathrm{RNA}, \mathrm{K}^{+}, \mathrm{Mg}^{2+}$ and $\mathrm{PO}_{4}{ }^{3-}$ contents which followed changes in the growth rate of $\mathrm{K}^{+}$-limited Aerobacter aerogenes cultures. The significance of these findings is discussed in relation to the control of ribosome structure and function for which, it is suggested, precise $\mathrm{K}^{+}: \mathrm{Mg}^{2+}$ ratios may be of fundamental importance. A preliminary report on our findings has been published (Dicks \& Tempest, 1966).

\section{METHODS}

Organism. Aerobacter aerogenes (NCTC 418) was maintained, and subcultured monthly on tryptic meat digest agar slopes.

Growth conditions. Cultures were grown in 0.5-1 chemostats of the design described by Herbert, Phipps \& Tempest (1965). Temperature was controlled automatically at $35^{\circ}$, and the $\mathrm{pH}$ value at $6 \cdot 5 \pm 0 \cdot 1$. Foaming of the culture was suppressed by the regular addition of small volumes (0.1-0.2 ml.) of Polyglycol P-2000 antifoam (Dow Chemical Co., Midland, Michigan, U.S.A.).

The culture medium (K+-limited) contained: $\mathrm{Na}_{2} \mathrm{HPO}_{4}, 5 \cdot 0 \times 10^{-3} \mathrm{M} ;\left(\mathrm{NH}_{4}\right)$ $\mathrm{H}_{2} \mathrm{PO}_{4}, 4.5 \times 10^{-2} \mathrm{M} ;\left(\mathrm{NH}_{4}\right)_{2} \mathrm{SO}_{4}, 2.5 \times 10^{-2} \mathrm{M}$; citric acid, $1.0 \times 10^{-3} \mathrm{M} ; \mathrm{MgCl}_{2}, 1.25 \times$ $10^{-3} \mathrm{M} ; \mathrm{CaCl}_{2}$ and $\mathrm{FeCl}_{3}$, each $1.0 \times 10^{-4} \mathrm{M} ; \mathrm{Mn}^{2+}, 2.5 \times 10^{-5} \mathrm{M} ; \mathrm{Cu}^{2+}$ and $\mathrm{Na}_{2} \mathrm{MoO}_{4}$, each $5.0 \times 10^{-6} \mathrm{M}$. Glycerol was added to a final concentration of $30 \mathrm{mg} . / \mathrm{ml}$. and $\mathrm{K}_{2} \mathrm{SO}_{4}$ to $5 \cdot 0 \times 10^{-4} \mathrm{M}$. Medium was prepared in $20 \mathrm{l}$. volumes with distilled water which had been passed through a mixed-bed ion-exchange resin column. The final $\mathrm{pH}$ value after autoclaving $\left(121^{\circ}, 30 \mathrm{~min}\right.$.) was about $5 \cdot 3$; the medium was adjusted to the $\mathrm{pH}$ value required for the growth of the organism in the culture vessel.

Analytical procedures. Bacterial concentration (mg. dry weight organism/ml. culture), and their RNA, DNA, carbohydrate and protein contents were determined 
by previously described methods (Tempest et al. 1965). Magnesium contents of organisms were determined by the method of Gardner (1946) on $0.5 \mathrm{~N}$ perchloric acid extracts of organisms. Traces of Polyglycol P-2000 present in these extracts interfered with the assay and were removed by treatment with light petroleum (b.p. $60^{\circ}-80^{\circ}$ ) (Tempest \& Strange, 1966). Total phosphorus was determined by the method of King (1932) after digestion of the organisms with $60 \%$ (w/v) perchloric acid.

Determination of bacterial potassium content. Difficulty was experienced in obtaining a reliable estimate of the $\mathrm{K}^{+}$content of growing organisms because the separation of the bacteria from the culture fluid and subsequent washing procedures generally resulted in the loss of some potassium from the organisms. Thus, more than $15 \%$ was lost when the organisms were washed once in saline, and over $40 \%$ when they were washed once in distilled water. It was found that no loss of $\mathbf{K}^{+}$ occurred when organisms were washed in $0 \cdot 1 \quad \mathrm{M}^{-} \mathrm{MgCl}_{2}$ solution ( $\mathrm{pH} \mathrm{6 \cdot 0-6 \cdot 5)}$. It was also found that the extracellular $\mathrm{K}^{+}$concentration in $\mathrm{K}^{+}$-limited cultures of Aerobacter aerogenes was exceedingly small; this simplified the problem by eliminating the necessity for washing these bacteria before determining their potassium content. A further difficulty due to the presence of interfering substances (principally phosphate) in the culture supernatant fluid and in bacterial extracts was overcome by adopting the following procedure for determining the distribution of $\mathbf{K}^{+}$in the cultures. Two $5 \mathrm{ml}$. samples of culture were collected, one of which was heated at $100^{\circ}$ for $5 \mathrm{~min}$. to release the $\mathrm{K}^{+}$from the organisms. Both samples were centrifuged $(3000 \mathrm{~g}, 5 \mathrm{~min}$.) and the clear supernatant fluids collected. These were analysed for potassium by using an E.E.L. Flame Photometer (mark II) and standard solutions of $\mathrm{K}^{+}\left(10-50 \mu \mathrm{g} . / \mathrm{ml}\right.$.) in $0.05 \mathrm{M}-\mathrm{Na}_{2} \mathrm{HPO}_{4}$ (i.e. the concentration of $\mathrm{PO}_{4}{ }^{3-}$ in the medium). With this method recovery of added $\mathrm{K}^{+}$was better than $98 \%$ and estimates of total $\mathrm{K}^{+}$in the culture were always within $3 \%$ of the amount initially added to the medium (taking into account dilution by $\mathrm{NaOH}$ additions necessary for $\mathrm{pH}$ control).

Determination of culture $Q_{\mathrm{O}_{2}}$ and $\mathbf{Q}_{\mathrm{CO}_{2}}$ values. These were calculated from the rates of air flow through the culture, the oxygen and carbon dioxide contents of the effluent gas (determined with a Beckman Model E-2 oxygen analyser and a Mines Safety Appliances Co. 'Lira' Infra-red $\mathrm{CO}_{2}$ Analyser), the culture volume and the bacterial concentration. The $Q_{\mathrm{O}_{2}}$ values of washed suspension of organisms were determined by standard techniques with a Warburg manometer.

Viability. Measurements were made by the slide culture technique described by Postgate, Crumpton \& Hunter (1961).

Storage. $\mathbf{0} \cdot 8-5.0 \mathrm{ml}$. volumes of culture were diluted with $\mathrm{K}^{+}$-free phosphate saline $(6.7 \mathrm{~mm}$-phosphate in $0.85 \%(\mathrm{w} / \mathrm{v}) \mathrm{NaCl} ; \mathrm{pH} \mathrm{6.4)}$ ) to contain the equivalent of $1 \mathrm{mg}$. dry wt. organism/ml. The suspension $(5 \mathrm{ml}$.) was centrifuged, and the deposited bacteria washed in $\mathbf{K}^{+}$-free phosphate saline, and resuspended in this buffer to a concentration equivalent to $20 \mu \mathrm{g}$. dry wt. organism $/ \mathrm{ml}$. The suspensions were incubated at $37^{\circ}$, with aeration, and viabilities determined at regular time intervals. 


\section{RESULTS}

\section{Influence of $\mathrm{K}^{+}$concentration and dilution rate on the 'steady-state' bacterial concentration}

Figure 1 shows the relationship between bacterial concentration and potassium content of Aerobacter aerogenes cultures grown at a dilution rate of $\mathbf{0 . 4} \mathrm{hr}^{-\mathbf{1}}$. The linear nature of this relationship indicates that growth was being limited by the availability of potassium, though it is apparent from the fact that the plot does not pass through the origin that some other substance (or substances) in the medium was supporting a small amount of growth of $A$. aerogenes, and could do so in the

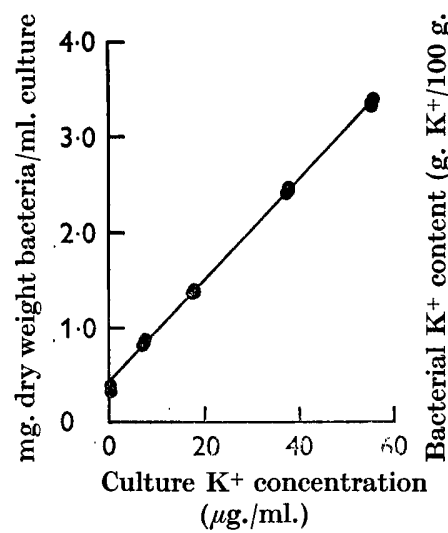

Fig. 1

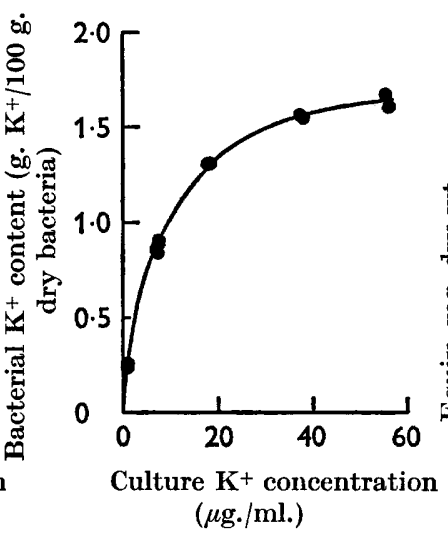

Fig. 2

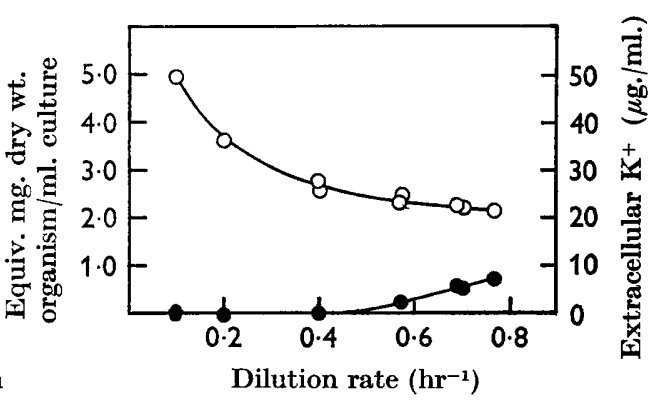

Fig. 3

Fig. 1. Plot of 'steady-state' concentration of Aerobacter aerogenes against culture $\mathbf{K}^{+-}$ concentration. Dilution rate fixed at $0 \cdot 4 \mathrm{hr}^{-1}$; temperature $35^{\circ} ; \mathrm{pH} 6.5$. Values determined over a period of 2-3 days, after initial equilibration of the culture for 2 days at each $\mathrm{K}^{+}$input concentration.

Fig. 2. Plot of 'steady-state' potassium content of Aerobacter aerogenes against culture $\mathrm{K}^{+}$-concentration. Dilution rate fixed at $0 \cdot 4 \mathrm{hr}^{-1}$; temperature $35^{\circ} ; \mathrm{pH} \mathrm{6.5}$. Values determined over a period of 2-3 days, after initial equilibration of the culture for 2 days at each $\mathrm{K}^{+}$concentration.

Fig. 3. Plot of 'steady-state' concentrations of Aerobacter aerogenes and extracellular $\mathbf{K}^{+}$ as a function of dilution rate. Values determined over a 2-3 day period at each dilution rate, and after at least 2 days equilibration. $\bigcirc, \mathrm{mg}$. dry wt. bacteria $/ \mathrm{ml}$. culture;,$\mu \mathrm{g}$. extracellular $\mathrm{K}^{+} / \mathrm{ml}$. culture.

virtual absence of potassium. Since all the culture $\mathrm{K}^{+}$was present in the organisms, it follows from Fig. 1 that the bacterial $\mathbf{K}^{+}$content varied with the culture $\mathbf{K}^{+}$ concentration. This is shown in Fig. 2. The probable explanation of this finding is that the sum of the $\mathrm{K}^{+}$and ' $\mathrm{K}^{+}$replacement factor' contents of the bacteria was constant, but the relative proportion of each depended on their concentration in the culture. Since the culture concentration of 'replacement factor' was constant, increasing the medium $\mathrm{K}^{+}$concentration resulted in progressive increases in bacterial $\mathrm{K}^{+}$content. The latter tended to a maximum value (about $1.5 \%$ of the bacterial dry weight) at concentrations above $40 \mu \mathrm{g} . \mathrm{K}^{+} / \mathrm{ml}$. culture, where, presumably, the growth contribution from 'replacement factor' was relatively insignificant. All subsequent experiments were carried out on organisms growing in the presence 
of about $40 \mu \mathrm{g}$. $\mathbf{K}^{+} / \mathrm{ml}$. culture (i.e. $1 \mathrm{~mm}-\mathrm{K}^{+}$). With such cultures the bacterial concentration varied markedly with the dilution rate (Fig. 3). This variation in yield (g. bacteria/g. $\mathrm{K}^{+}$) was similar to that observed by Tempest et al. (1965) with $\mathrm{Mg}^{2+}$-limited cultures of this organism and by Dr D. Herbert (personal communication) with $\mathrm{PO}_{4}{ }^{3-}$-limited cultures. A similar pattern of change has been reported

\section{Table 1. Gross composition of $K^{+-l i m i t e d ~ A e r o b a c t e r ~ a e r o g e n e s ~}$} organisms grown in a chemostat at different dilution rates

The figures quoted in this table are average values from at least three samples collected, processed and analysed on separate days. At each dilution rate (D) the culture 'steady-state' viability was greater than $90 \%$.

\begin{tabular}{|c|c|c|c|c|c|}
\hline & Protein & $\begin{array}{c}\text { Acid sol. } \\
\text { material } \\
\text { (as RNA) }\end{array}$ & RNA & DNA & $\begin{array}{l}\text { Carbo- } \\
\text { hydrate }\end{array}$ \\
\hline D & \multicolumn{5}{|c|}{ g. component/100 g. lyophilized bacteria } \\
\hline $0 \cdot 1$ & $72 \cdot 9$ & $1 \cdot 2$ & $7 \cdot 3$ & $2 \cdot 2$ & $2 \cdot 5$ \\
\hline $\mathbf{0 \cdot 2}$ & $73 \cdot 3$ & $1 \cdot 4$ & $11 \cdot 7$ & $\mathbf{1} \cdot \mathbf{8}$ & $\mathbf{2 \cdot 8}$ \\
\hline $0 \cdot 4$ & $72 \cdot 5$ & $1 \cdot 3$ & $15 \cdot 0$ & $2 \cdot 4$ & $\mathbf{3 \cdot 6}$ \\
\hline $0 \cdot 6$ & $73 \cdot 8$ & $1 \cdot 2$ & $17 \cdot 4$ & $2 \cdot 6$ & $4 \cdot 0$ \\
\hline $0 \cdot 8$ & $67 \cdot 6$ & $1 \cdot 6$ & $17 \cdot 6$ & $2 \cdot 1$ & $4 \cdot 7$ \\
\hline
\end{tabular}

Table 2. Potassium, magnesium and phosphorus contents of Aerobacter aerogenes organisms grown in a chemostat at different dilution rates $(D)$

\begin{tabular}{|c|c|c|c|}
\hline \multirow{2}{*}{$\underset{\text { (vol./hr.) }}{\text { D }}$} & \multicolumn{3}{|c|}{ Component } \\
\hline & \multicolumn{3}{|c|}{ g. component/100 g. dry bacteria } \\
\hline $0 \cdot 09$ & $0 \cdot 81$ & $0 \cdot 124$ & - \\
\hline $0 \cdot 10$ & $0 \cdot 80$ & $0 \cdot 122$ & $1 \cdot 31$ \\
\hline $\mathbf{0} \cdot 19$ & $1 \cdot 07$ & $0 \cdot 156$ & $1 \cdot 69$ \\
\hline $0 \cdot 21$ & $1 \cdot 09$ & $0 \cdot 163$ & - \\
\hline $0 \cdot 37$ & $1 \cdot 38$ & $\mathbf{0} \cdot \mathbf{1 8 9}$ & - \\
\hline $0 \cdot 38$ & $1 \cdot 45$ & $0 \cdot 188$ & - \\
\hline 0.40 & $1 \cdot 40$ & $0 \cdot 198$ & $2 \cdot 02$ \\
\hline $0 \cdot 40$ & $1 \cdot 49$ & $0 \cdot 200$ & $\mathbf{2 \cdot 3 2}$ \\
\hline 0.56 & $\mathbf{1} \cdot 59$ & $0 \cdot 211$ & - \\
\hline $0 \cdot 57$ & 1.55 & 0.227 & $2 \cdot 38$ \\
\hline 0.58 & $1 \cdot 47$ & $0 \cdot 208$ & $\mathbf{2 \cdot 2 3}$ \\
\hline $0 \cdot 69$ & $1 \cdot 45$ & $0 \cdot 231$ & $2 \cdot 44$ \\
\hline $0 \cdot 70$ & $\mathbf{1 . 5 1}$ & $0 \cdot 224$ & $\mathbf{2} \cdot \mathbf{3 9}$ \\
\hline 0.76 & $1 \cdot 68$ & - & - \\
\hline 0.77 & $1 \cdot 46$ & 0.212 & $2 \cdot 56$ \\
\hline
\end{tabular}

with $\mathrm{NH}_{4}{ }^{+}$-limited cultures (Holme, 1957; Herbert, 1961) which resulted from a gross variation in the polysaccharide content of the organisms. The changes in polysaccharide content of $\mathrm{K}^{+}$-limited $\boldsymbol{A}$. aerogenes with dilution rate (Table 1 ) could not account for the above yield variation. 
Variation in bacterial macromolecular composition with changes in growth rate

The protein, RNA, DNA and carbohydrate contents of $\mathrm{K}^{+}$-limited Aerobacter aerogenes, grown at five different dilution rates, are detailed in Table 1 . Whereas irregular patterns of change were apparent in bacterial DNA and protein contents, both the RNA and carbohydrate contents increased progressively with dilution rate. The variation in RNA content of these organisms was similar in amount to those observed with other types of growth limitation (Tempest et al. 1965) and with other organisms (Herbert, 1961; Neidhardt, 1963), and were most probably due to variations in the ribosome content of organisms (Ecker \& Schaechter, 1963). The changes in bacterial polysaccharide content were similar to those observed with $\mathrm{Mg}^{2+-}$-limited cultures (Tempest et al. 1965) and opposite to those with $\mathrm{NH}_{4}{ }^{+}$-limited organisms (Herbert, 1958).

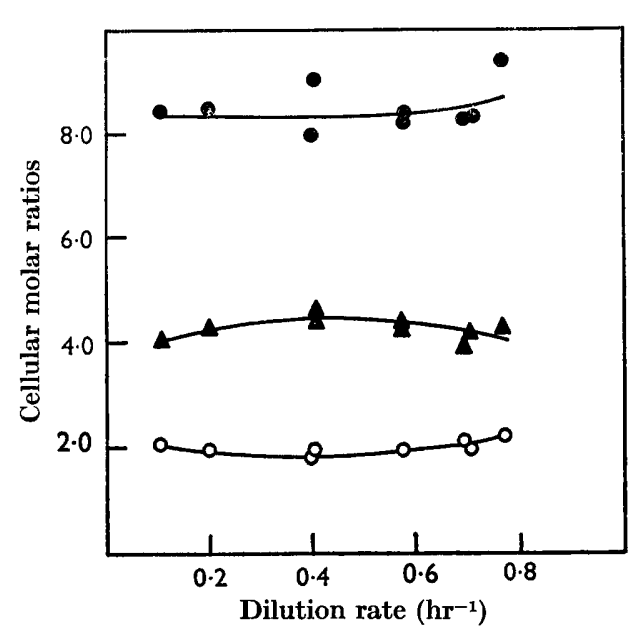

Fig. 4

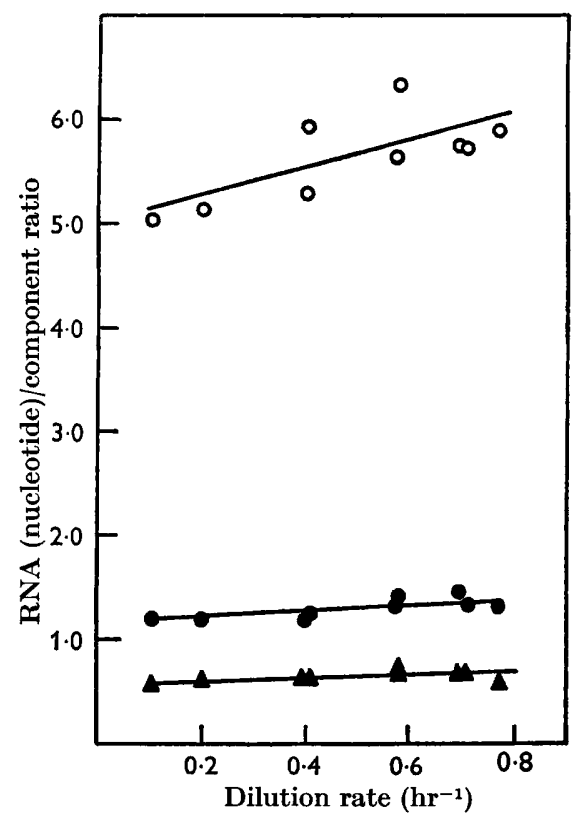

Fig. 5

Fig. 4. Stoichiometry between intracellular potassium, magnesium and phosphorus in chemostat cultures of Aerobacter aerogenes grown at different dilution rates. Molar ratios of: $O$, phosphorus : potassium; $\boldsymbol{O}$, phosphorus: magnesium; $\boldsymbol{\Delta}$, potassium:magnesium. Fig. 5. Stoichiometry between cellular RNA and potassium, magnesium and phosphorus in chemostat cultures of Aerobacter aerogenes grown at different dilution rates. Molar ratios of: $\bigcirc$, RNA (nucleotide): magnesium; $\bullet$, RNA (nucleotide): potassium; $\Delta, \mathbf{R N A}$ (nucleotide): phosphorus.

\section{Variations in bacterial potassium, magnesium and phosphorus contents with changes in growth rate}

The changes in bacterial growth yield with dilution rate (Fig. 3) indicated a correlation between the $\mathrm{K}^{+}$content of $\mathrm{K}^{+}$-limited Aerobacter aerogenes organisms and their rate of growth. As similar correlations have been found with the $\mathbf{M g}^{2+}$ content of $A$. aerogenes (Tempest et al. 1965; Tempest \& Strange, 1966) and the 
phosphorus content of Escherichia coli (Wade, 1952), the $\mathrm{K}^{+}, \mathrm{Mg}^{2+}$ and $\mathbf{P}$ contents of $\mathbf{K}^{+}$-limited $\boldsymbol{A}$. aerogenes organisms were determined at several 'steady-state' growth rates between $0.09 \mathrm{hr}^{-1}$ and $0.77 \mathrm{hr}^{-1}$ (Table 2). The corresponding molar $\mathrm{K}^{+}: \mathrm{Mg}^{2+}, \mathbf{P}: \mathrm{Mg}^{2+}$ and $\mathbf{P}: \mathrm{K}^{+}$ratios (Fig. 4) show that the intracellular concentrations of all three components were similarly influenced by growth rate and the molar ratios (approximately $1: 4: 8$, for $\mathrm{Mg}^{2+}: \mathrm{K}^{+}: \mathrm{P}$ ) were almost independent of growth rate. Furthermore these changes paralleled changes in bacterial RNA content (Table 1 ) as is evident from the molar RNA (nucleotide): $\mathrm{Mg}^{2+}$ and $\mathrm{RNA}: \mathrm{K}^{+}$ratios, shown in Fig. 5.

\section{Changes in the respiratory activity of $\boldsymbol{K}^{+}$-limited} Aerobacter aerogenes cultures with growth rate

Herbert (1958) reported the $\boldsymbol{Q}_{\mathrm{O}_{2}}$ and $\boldsymbol{Q}_{\mathrm{Co}_{2}}$ values of glycerol-limited Aerobacter aerogenes cultures varied from 150 to 485 and 115 to 400 , respectively, as the dilution rate was increased from $0 \cdot 1$ to $\mathbf{0 \cdot 6} \mathrm{hr}^{-1}$; comparative figures for $\mathrm{K}^{+}$-limited cultures of this organism are shown in Table 3 . In carbon-limited cultures the rate of oxygen uptake must reflect the minimum rate of substrate oxidation necessary to support the growth of organisms at the imposed rate. The values reported in Table 3 are clearly much larger than these estimated minima (i.e. $Q_{\mathrm{o}_{2}}$ of 150 at $\mathrm{D}=0 \cdot 1 \mathbf{h r}^{-1}$ and 485 at $\mathrm{D}=0.6 \mathrm{hr}^{-1}$ ), suggesting that the growth of $\mathrm{K}^{+}$-limited $A$. aerogenes was not restricted by its ability to oxidize the carbon source (glycerol) at the necessary rate. This conclusion was supported by the observation that washed suspensions of $\mathrm{K}^{+}$-limited organisms (grown at a dilution rate of $0.2 \mathrm{hr}^{-1}$ ), which contained substantially less potassium than that present during growth because they had been washed in water, oxidized glycerol at a rate which was not influenced by the presence of $10 \mathrm{~mm} \mathrm{~K} \mathrm{~K}^{+}$in the suspending medium $\left(Q_{\mathrm{o}_{2}}=201\right)$. These organisms also oxidized glucose, without delay, at a rate which was only slightly increased by $10 \mathrm{~mm} \mathrm{~K} \mathrm{~K}^{+}\left(Q_{\mathrm{O}_{2}}\right.$ values of 266 and 273 , respectively).

Table 3. Influence of dilution rate on the respiratory activity of $\boldsymbol{K}^{+-l i m i t e d}$ Aerobacter aerogenes cultures grown in a chemostat

Average 'steady-state' values measured over 2-4 days.

\begin{tabular}{ccc}
$\begin{array}{c}\text { Dilution rate } \\
\left(\mathrm{hr}^{-1}\right)\end{array}$ & $\begin{array}{c}\text { Oxygen uptake } \\
\mu l . / \text { equiv. mg. dry } \mathrm{CO}_{2} \text { output } \\
\text { wt. bacteria/hr }\end{array}$ \\
\cline { 2 - 3 } $0 \cdot 1$ & 289 & $\mathbf{3 1 5}$ \\
$0 \cdot 2$ & 375 & 436 \\
$0 \cdot 4$ & 574 & 634 \\
$0 \cdot 6$ & 721 & 720
\end{tabular}

\section{Effect of storage, in the presence and absence of glycerol,} on the viability of washed $\boldsymbol{K}^{+-}$-limited Aerobacter aerogenes

Routine viability measurements on $\mathrm{K}^{+}$-limited Aerobacter aerogenes cultures, grown at several dilution rates, showed the presence of more non-viable organisms (i.e. up to $10 \%$ of the population at some dilution rates) than had been encountered with corresponding glycerol-limited or $\mathrm{Mg}^{2+}$-limited cultures (Tempest et al. 1965). Experiments were done, therefore, to determine the death-rate of $\mathrm{K}^{+}$-limited $A$. aerogenes in the presence and absence of a carbon + energy source (glycerol). 
Figure 6 shows the changes in viability with time of saline-phosphate-washed bacteria from $\mathrm{K}^{+}$-limited Aerobacter aerogenes cultures, grown at several different dilution rates and incubated at $37^{\circ}$ in aerated phosphate saline (pH 6.5). The deathrate correlates with the dilution rate; the higher the dilution rate at which organisms were grown, the longer they survived in the non-nutrient environment (cf. Postgate \& Hunter, 1962). $\mathrm{K}^{+}(15 \mathrm{mM})$ did not significantly influence the death-rate of these starved $\mathrm{K}^{+}$-limited bacteria, but glycerol was markedly toxic (Fig. 7). The toxicity of glycerol for washed $\mathrm{K}^{+}$-limited $\boldsymbol{A}$. aerogenes was reduced by the addition of either $15 \mathrm{~mm} \mathrm{~K} \mathrm{~K}^{+}$or $15 \mathrm{~mm} \mathrm{Mg} \mathrm{Mg}^{2+}$ to the suspension fluid; mixtures of these ions totally prevented glycerol-accelerated death of these populations (Fig. 7).

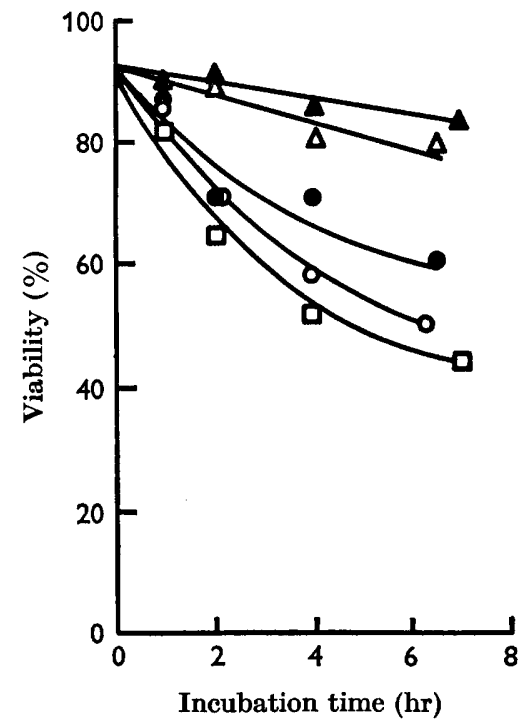

Fig. 6

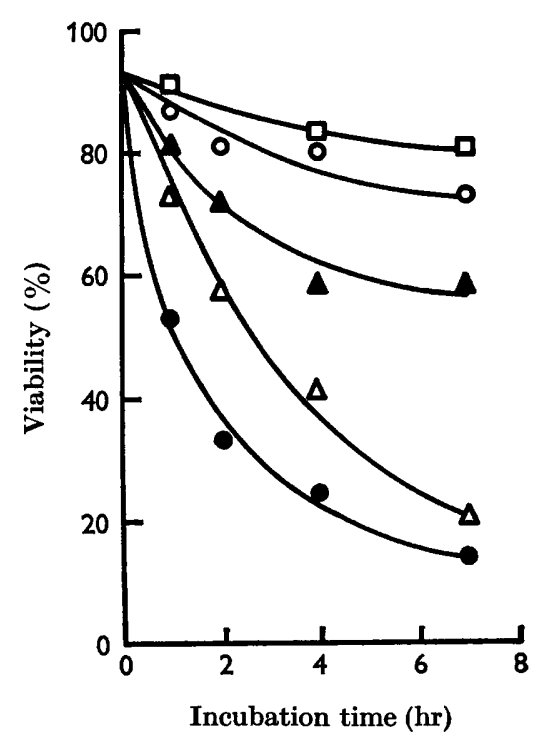

Fig. 7

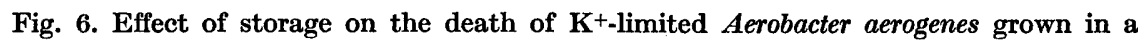
chemostat at different dilution rates. Organisms were washed, suspended in phosphate saline (pH 6.5), aerated and incubated at $37^{\circ}$. Viabilities were determined by slide culture. Organisms were grown at dilution rates of: $\square, 0.1 \mathbf{h r}^{-1} ; 0,0.2 \mathbf{h r}^{-1} ; 0,0.4 \mathbf{h r}^{-1}$; $\triangle, 0.6 \mathrm{hr}^{-1} ; \Delta, 0.8 \mathrm{hr}^{-1}$.

Fig. 7. Effect of potassium and/or magnesium on glycerol-accelerated death of $\mathbf{K}^{+}$limited Aerobacter aerogenes. Organisms were grown at a dilution rate of $0.6 \mathrm{hr}^{-1}$ (temperature $35^{\circ} ; \mathrm{pH} \mathrm{6.5)}$, washed and suspended in phosphate saline (pH 6.5). Suspensions were aerated and incubated at $37^{\circ}$ in the presence of: $0,10 \mathrm{~mm}$-glycerol; $\triangle, 10 \mathrm{~mm}$-glycerol +15 mM K+ ; $\Delta, 10 \mathrm{~mm}$ glycerol + $15 \mathrm{mM} \mathrm{Mg}^{2+} ; \square, 10 \mathrm{~mm}$ glycerol + $15 \mathrm{~mm} \mathrm{~K} \mathrm{~K}^{+}+15 \mathrm{~mm}$ $\mathrm{Mg}^{2+}$. No additions were made to the control suspension (O).

\section{DISCUSSION}

Although the 'steady-state' concentration of Aerobacter aerogenes at a fixed dilution rate was a function of the culture $\mathbf{K}^{+}$-concentration, the extrapolated plot did not pass through the origin, thus suggesting the organisms did not have an absolute potassium requirement for growth. It has been reported that rubidium can replace potassium for the growth of bacteria (Eddy \& Hinshelwood, 1950; 
Lester, 1958) but this element was not intentionally added to the medium and, as a contaminant of the salts used in compounding the medium, would have to be present in a concentration of $\mathbf{0} \cdot 15-0.2 \mathrm{~mm}$ (assuming the molar-growth yield to be similar to that for potassium) to account for the apparent degree of growth in the complete absence of potassium. Although the most obvious explanation for the observed growth of $\boldsymbol{A}$. aerogenes in the absence of potassium is the presence of a substance, such as rubidium, which can substitute, functionally, for potassium, other explanations are possible. For example, errors in the determination of either culture bacterial dry weight or $\mathrm{K}^{+}$concentration could produce the result observed. However, duplicate determinations of bacterial dry weights never varied by more than $5 \%$, and day-to-day variations in the culture dry weights were also small (Fig. 1); lysis of organisms was not observed. The potassium assay was thoroughly checked; determinations of potassium present in the culture always agreed closely with that calculated to be present, amounts of potassium added to the culture were quantitatively recovered and hot water extracts of $\mathbf{K}^{+}$-limited bacteria contained amounts of potassium equal to that detected in the whole culture (little potassium being present in the extracellular fluid of cultures growing at a dilution rate of $0 \cdot 4 \mathrm{hr}^{-1}$ ).

The limited amount of growth observed in the absence of added potassium has theoretical implications. Thus, the yield of organisms (g. bacteria/g. $\mathbf{K}^{+}$) varied with culture $\mathrm{K}^{+}$concentration and tended to infinity as the culture $\mathrm{K}^{+}$concentration approached zero. Bacterial growth yields are generally supposed to be independent of the growth-limiting substrate input concentration (Monod, 1950; Herbert, Elsworth \& Telling, 1956; Powell, 1965); clearly this is only true when the organisms have an absolute requirement for the growth-limiting component of the medium. Although in our experiments the growth yield varied with culture $\mathrm{K}^{+}$concentration, the 'incremental yield' (increase in dry weight/unit increase in culture $\mathbf{K}^{+}$concentration) was constant. The incremental yield and growth yield (defined above) are equal when the organisms have a specific, and absolute, requirement for the growthlimiting component of the medium; that is, when the plot of culture bacterial concentration against limiting component concentration passes through the origin.

The marked variation in culture bacterial concentration with dilution rate was almost identical to that observed with $\mathrm{Mg}^{2+}$-limited and $\mathrm{PO}_{4}{ }^{3-}$-limited cultures of Aerobacter aerogenes; this suggested that the bacterial $\mathrm{K}^{+}, \mathrm{Mg}^{2+}$ and phosphorus contents were each functions of the growth rate. This was clearly so with $\mathbf{K}^{+}$limited organisms (Table 2) and the observed growth-rate-independent stoichiometry between these three components (Fig. 3) implied a functional interrelationship. The only major macromolecular component of bacteria the concentration of which is invariably a function of growth rate (at a fixed temperature) is the RNA (Herbert, 1961; Neidhardt, 1963, Rosset, Monier \& Julien, 1964), or more specifically the bacterial ribosome content (Ecker \& Schaechter, 1963). The stoichiometry between $\mathrm{RNA}, \mathrm{K}^{+}, \mathrm{Mg}^{2+}$ and phosphorus contents of $A$. aerogenes (Fig. 4) is strongly indicative of $\mathrm{K}^{+}$and $\mathrm{Mg}^{2+}$ involvement in RNA (presumably ribosome) synthesis and function. Magnesium is a structural component of ribosomes (Tissières \& Watson, 1958; Rodgers, 1964) and the magnesium content of bacteria varies with their ribosome content (Tempest \& Hunter, 1965; Tempest \& Strange, 1966). The structural integrity and functional ability of ribosomes may, however, require other 
cations beside $\mathrm{Mg}^{2+}$. The degree of aggregation, and the stability, of ribosomes in vitro depends not only on the concentration of $\mathrm{Mg}^{2+}$ in the environment, but on the monovalent cation: $\mathrm{Mg}^{2+}$ ratio (Petermann, 1964; Cammack \& Wade, 1965). The close correlation between the $\mathrm{K}^{+}$and $\mathrm{Mg}^{2+}$ contents of growing $A$. aerogenes suggests, therefore, that the high intracellular $\mathrm{K}^{+}$concentration observed may be required to maintain ribosomal structures in a suitable functional configuration or state of aggregation.

A large proportion of the potassium of growing Aerobacter aerogenes organisms was leached from the organisms by suspension in distilled water, without significant effect on their oxidative metabolism and viability. However, these organisms did not synthesize protein when suspended in a $\mathbf{K}^{+}$-free, but otherwise complete medium (unpublished observation). This agreed with the conclusions of Ennis \& Lubin (1961) and of Anderson (1966) that potassium depletion impaired the ability of organisms to synthesize protein. On the other hand, Strange \& Shon (1964) observed that heat-shocked $A$. aerogenes rapidly lost RNA and viability when suspended and aerated in high concentrations of $\mathrm{K}^{+}$. They interpreted this result as indicating an increased uptake of $\mathrm{K}^{+}$by the organisms and breakdown of ribosomal structures because of $\mathrm{K}^{+}: \mathrm{Mg}^{2+}$ imbalance. These observations reinforce the view that a critical intracellular $\mathrm{K}^{+}: \mathrm{Mg}^{2+}$ ratio may be essential for protein synthesis to occur at the maximum rate; excretion of $\mathbf{K}^{+}$, such as occurs when bacterial growth ceases (Eddy, Carroll, Danby \& Hinshelwood, 1951), may be the mechanism whereby protein synthesis is initially halted-particularly when growth ceases through the depletion of some nutrient other than the carbon and nitrogen sources.

Because potassium is rapidly lost from organisms which cease to grow and, in $\mathrm{K}^{+}$-limited cultures, would be immediately taken up by the growing organisms, changes in the yield and bacterial $\mathrm{K}^{+}$content of such cultures with dilution rate might be caused merely by a large variation in culture viability. Viabilities were, on the whole, lower in $\mathrm{K}^{+-}$limited Aerobacter aerogenes cultures than in corresponding glycerol-limited or $\mathrm{Mg}^{2+-l i m i t e d ~ c u l t u r e s ~(T e m p e s t ~ e t ~ a l . ~ 1965), ~ b u t ~ n e v e r t h e l e s s ~}$ they were always more than $90 \%$ and therefore do not undermine the significance of the observed quantitative relationships between $\mathrm{RNA}, \mathrm{K}^{+}, \mathrm{Mg}^{2+}$ and phosphorus in these organisms. Variations in culture viability with dilution rate did occur, but were slight; viabilities were marginally higher in the faster-growing cultures which correlated with their decreased susceptibility to death by starvation (Fig. 5). The

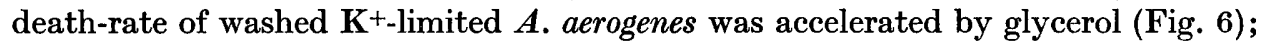
thus, the presence of excess glycerol in $\mathrm{K}^{+}$-limited cultures may have had an effect on viability. Magnesium ion prevented glycerol-accelerated death of other organisms (Postgate \& Hunter, 1964; Strange \& Dark, 1965) and were present in excess of requirement in the $\mathrm{K}^{+}$-limited $A$. aerogenes cultures. However, $\mathrm{Mg}^{2+} \operatorname{did}$ not abolish the toxicity of glycerol for $\mathbf{K}^{+}$-limited organisms, except when added in the presence of $\mathrm{K}^{+}$(Fig. 6).

The authors are indebted to Dr D. Herbert and Mr R. E. Strange for many useful discussions during the progress of this work. We also thank Mr T. H. Dunham for his skilled technical assistance. 


\section{REFERENCES}

Anderson, J. D. (1966). Biochemical studies of lethal processes in aerosols. J. gen. Microbiol. (in the Press).

Cammack, K. A. \& WADE, H. E. (1965). The sedimentation behaviour of ribonucleaseactive and -inactive ribosomes from bacteria. Biochem. J. 96, 671 .

Dicks, J. W. \& Tempest, D. W. (1966). Potassium metabolism in Aerobacter aerogenes. Biochem. J. 99, 7P.

Dixon, M. \& Wrbb, E. C. (1958). Enzymes. London: Longmans Green and Co. Ltd.

Ecker, R. E. \& Schaechter, M. (1963). Ribosome content and the growth of Salmonella typhimurium. Biochim. biophys. Acta 76, 275.

EDDY, A. A. \& Hinshelwood, C. N. (1950). The utilization of potassium by Bacterium lactis aerogenes. Proc. R. Soc. B, 136, 544.

EDdy, A. A. \& Hinshelwood, C. N. (1951). Alkali-metal ions in the metabolism of Bact. lactis aerogenes. III. General discussion of their role and mode of action. Proc. R. Soc. B, 138, 237.

Eddy, A. A., Carroll, T. C. N., Danby, C. J. \& Hinshelwood, C. N. (1951). Alkalimetal ions in the metabolism of Bact. lactis aerogenes. I. Experiments on the uptake of radioactive potassium, rubidium and phosphorus. Proc. $R$. Soc. B, 138, 219.

EnNIs, H. L. \& LuBIN, M. (1961). Dissociation of ribonucleic acid and protein synthesis in bacteria deprived of potassium. Biochim. biophys. Acta 50, 399.

Ennis, H. L. \& Lubin, M. (1965). Pre-ribosomal particles formed in potassium depleted cells. Studies on degradation and stabilisation. Biochim. biophys. Acta 95, 605.

GARDNER, R. J. (1946). Colorimetric determination of magnesium in plasma or serum by means of titan yellow. Biochem. J. 40, 828 .

Herbert, D. (1958). Some principles of continuous culture. In Recent Progress in Microbiology, VIIth Int. Congr. Microbiol. p. 381.

Herbert, D. (1961). The chemical composition of micro-organisms as a function of their environment. Symp. Soc. gen. Microbiol. 11, 391.

Herbert, D., Elsworth, R. \& Telling, R. C. (1956). The continuous culture of bacteria; a theoretical and experimental study. J. gen. Microbiol. 14, 601.

Herbert, D., Phipps, P. J. \& Tempest, D. W. (1965). The chemostat: design and instrumentation. Lab. Practice 14, 1150.

HoLme, 'T. (1957). Continuous culture studies on glycogen synthesis in Escherichia coli $B$. Acta chem. scand. 11, 763.

KING, E. J. (1932). The colorimetric determination of phosphorus. Biochem. J. 26, 292.

LESTER, G. (1958). Requirement for potassium by bacteria. J. Bact. 75, 426.

Lubin, M. \& Kessel, D. (1960). Preliminary mapping of the genetic locus for potassium transport in Escherichia coli. Biochem. Biophys. Res. Commun. 2, 249.

Monod, J. (1950). La technique de culture continué; théorie et applications. Ann. Inst. Pasteur 79, 390.

NeIDHaRd, F. C. (1963). Effect of environment on the composition of bacterial cells. Annu. Rev. Microbiol. 17, 61.

Petermann, M. (1964). The physical and chemical properties of ribosomes. Amsterdam: Elsevier.

Postgate, J. R. \& Hunter, J. R. (1962). The survival of starved bacteria. J. gen. Microbiol. 29, 233.

Postgate, J. R. \& Hunter, J. R. (1964). Accelerated death of Aerobacter aerogenes starved in the presence of growth-limiting substrates. J. gen. Microbiol. 34, 459.

Postgate, J. R., Crumpton, J. E. \& Hunter, J. R. (1961). The measurement of bacterial viabilities by slide culture. J. gen. Microbiol. 24, 15.

Poweln, E. O. (1965). Theory of the chemostat. Lab. Practice 14, 1145.

Roberts, R. B., Roberts, Z. \& CowIE, D. B. (1949). Potassium metabolism in Escherichia coli. 2. Metabolism in presence of carbohydrates and their metabolic derivatives. $J$. cellular comp. Physiol. 34, 259. 
RoDgers, A. (1964). The exchange properties of magnesium in Escherichia coli ribosomes. Biochem. J. 90, 548.

Rosset, R., Monier, R. \& Julien, J. (1964). RNA composition of Escherichia coli as a function of growth rate. Biochem. biophys. Res. Commun. 15, 329.

RouF, M. A. (1964). Spectrochemical analysis of inorganic elements in bacteria. J. Bact. 88,1545 .

Strange, R. E. \& Dark, F. A. (1965). 'Substrate-accelerated death' of Aerobacter aerogenes. J. gen. Microbiol. 39, 215.

Strange, R. E. \& Shon, M. (1964). Effects of thermal stress on viability and ribonucleic acid of Aerobacter aerogenes in aqueous suspension. J. gen. Microbiol. 34, 99.

Tempest, D. W. \& HunTer, J. R. (1965). The influence of temperature and $\mathrm{pH}$ value on the macromolecular composition of magnesium-limited and glycerol-limited Aerobacter aerogenes growing in a chemostat. J. gen. Microbiol. 41, 267.

Tempest, D. W. \& Strange, R. E. (1966). Variation in content and distribution of magnesium, and its influence on survival, in Aerobacter aerogenes grown in a chemostat. J. gen. Microbiol. (in the Press).

Tempest, D. W., Hunter, J. R. \& Sykes, J. (1965). Magnesium-limited growth of Aerobacter aerogenes in a chemostat. J. gen. Microbiol. 39, 355.

Tissières, A. \& Watson, J. D. (1958). Ribonucleoprotein particles from Escherichia coli. Nature, Lond. 182, 778.

WADE, H. E. (1952). Variation in the phosphorus content of Escherichia coli during cultivation. J. gen. Microbiol. 7, 24. 